\title{
Commentary: Fierce urgencies and saving lives now
}

\author{
Ashish S. Shah, MD
}

From the Department of Cardiac Surgery, Vanderbilt University Medical Center, Nashville, Tenn Disclosures: Author has nothing to disclose with regard to commercial support.

Received for publication June 23, 2019; accepted for publication June 25, 2019; available ahead of print Aug 14, 2019.

Address for reprints: Ashish S. Shah, MD, Department of Cardiac Surgery, Vanderbilt University Medical Center, 5025 Medical Center East, 1215 21st Ave South, Nashville, TN 37232 (E-mail: ashish.s.shah@vanderbilt.edu). J Thorac Cardiovasc Surg 2020;159:511 0022-5223/\$36.00

Copyright (C) 2019 Published by Elsevier Inc. on behalf of The American Association for Thoracic Surgery https://doi.org/10.1016/j.jtcvs.2019.06.083

Rivaling the efforts in the United States in space during the 1960s, 20th century clinical heart transplantation galvanized multidisciplinary teams to solve seemingly impossible problems. The nagging issue, despite these heroic efforts, has been donor scarcity and the ongoing urgency of patients dying of almost epidemic heart failure in all its flavors. In the 21 st century, expanding current donor pools will be focused on reconditioning imperfect hearts. Using hepatitis $\mathrm{C}$-infected organs in uninfected recipients is the first landmark effort. Moayedi and colleagues ${ }^{1}$ have beautifully summarized this current early state.

Using hepatitis $\mathrm{C}$-infected hearts is predicated on the disturbing notion of intentionally infecting someone with a potentially lethal virus to save their life. The first cases certainly tested program and patient courage. But the drug efficacy and patient desperation have quickly emboldened them. Patients have fully embraced the idea, and use has grown quickly in the course of 2 to 3 years. Of the 100 heart transplants performed at Vanderbilt in 2018, one-third used hepatitis $\mathrm{C}$ hearts. This was almost entirely driven by our patients requesting access and consenting willingly.

Our own efforts at Vanderbilt, now approximately 100 recipients of hepatitis $\mathrm{C}$ hearts, were initiated by our hepatology colleagues urging us to use these hearts. They educated our team on the extraordinary drug efficacy of the new antiviral agents. With a vulnerable group of patients marginally supported by dysfunctional ventricular assist devices and without the luxury of time, our program decided to explore and recondition these hearts. Our results have been gratifying and, compared with the alternatives, remains the foundation of our continued enthusiasm.

Moayedi and colleagues ${ }^{1}$ recommend caution and raise many important issues. Having a collaborative medical and functional administrative infrastructure to manage these patients is critical. The long-term consequences are unknown. However, it is important to recognize the true

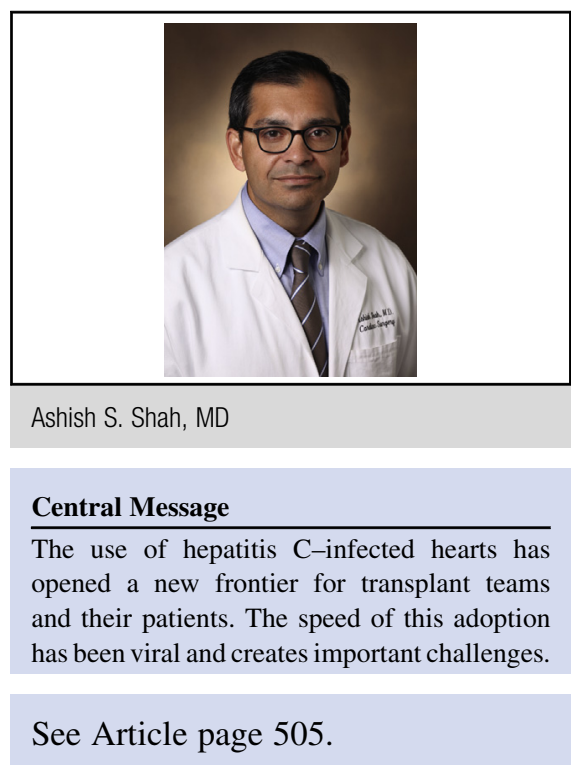

competing hazard here: death and crushingly poor quality of life.

A fair criticism of this entire enterprise is that heart transplantation is an expensive anecdote. Helping a few thousand patients a year when millions suffer with heart failure, particularly with expensive therapies and complex care teams, all seems foolish. Here again, similarities to the space program are relevant. What we will learn from saving these thousands of lives will enrich the lives of millions. Making dysfunctional hearts functional for transplant will unlock secrets to salvage hearts in situ and obviate the need for transplant.

It is clear that reconditioning strategies, either ex vivo or in vivo, are an important frontier for programs to explore. It may not address the persistent long-term complications of heart transplantation, but it can address the fierce urgency of now and offer a future for many patients.

\section{Reference}

1. Moayedi Y, Gulamhusein AF, Kush KK. Treading lightly as we step into a new era: use of hepatitis C virus-infected organs for transplantation. J Thorac Cardiovasc Surg. 2020;159:505-10. 